\title{
THE VALUE EDUCATION OF QOSIDAH BURDAH ARTS IN BOARDING SCHOOL IN THE LAND OF SUNDA
}

\author{
By \\ Sulasman, \\ State Islamic University of Sunan Gunung Djati Bandung \\ Email : sulasman@uinsgd.ac.id
}

\begin{abstract}
Burdah Al-Bushiri contains a string of poems of praise to the Prophet Muhammad. Burdah is a literary work of Sharafuddin Abu Abdillah Muhammad Ibn Zaid Al Bushiri.Burdah Al-Bushiri widely taught in boarding school. Boarding School teaches a lot of Value educations. Value educations contained in Burdah Al-Bushiri be internalized through the medium of art, the art of Qosidah Burdah. This article aims to explain values contained in Qosidah Burdah. To explain this purpose, used literature. Thus, we will know about values of educationcontained in Qosidah Burdah. The results showed that Values contained in Qosidah Burdah has affected the attitude and character of students at the boarding school. Boarding School has been instrumental in instilling the values of theological, juridical, socio-cultural Islam, and Sufi values contained in Art Qosidah Burdah. Sufistic value of Qosidah Burdah in boarding implanted with the aim to cleanse the heart from all impurities soul. Values contained in Qosidah Burdah among others about repentance, asceticism, patience, sincerity, trust, and mahabbah. To give meaning passion in poetry Qosidah Burdah and soul enlightenment for students at the school, then do internalization of sufistic values from Qosidah Burdah through the art of music. Burdah Qosidah Music Arts at the school in addition is also used as a tool to improve and help the personal and social students.
\end{abstract}

Keywords: Education, Values, Art, Burdah, Boarding School

\section{Introduction}

Boarding School that traditional Islamic education institutions to learn, understand, explore, appreciate and practice the teachings of Islam, stressing the importance of religious morals to guide daily behavior or tafaqquh fiddin (Mastuhu, 1994; 55). According to Hasan Basri (2001) in carrying out its functions, Boarding School have the main principles are adhered to, namely faith, devotion, voluntary, simplicity, wisdom, unity, independence, sincerity, the practice of religion, and compliance. Those principles are universal truth, and basically the same as the value of virtue in public life in general. With these values, then in the life of Boarding School is created a culture of peace, comfort and harmony. Those values are achieved through value education.

Educational value in Boarding School covers an action to educate students that took place ranging from attempted resuscitation value, until the realization of valuable behaviors. Educational value in Boarding School, leading the national education goals, which is to be human faith, devoted to God Almighty, noble, physically and mentally healthy, hardworking, independent, aesthetic, knowledgeable, creative, productive, able to compete, capable, democratic, have insight 
excellence, harmony with the natural environment, social responsibility, and have the spirit of nationality, in order to achieve the life of the nation. Educational value in Boarding School can be done by using instructional media. One medium that can be used is an art.

Art which is emerging in Boarding School is art that is calligraphy, martial arts, music like Qosidah, Tambourine, Marawis, Harp, etc. With regard to the art of music, many of Boarding School which formed artistic groups to develop their interests and talents of the students. They collaborate with the art of equipping modern art such as guitar, organ, etc. In addition to developing the artistic talents of the students, the arts in Boarding School also is used as a medium of dakwah. In addition, the art community is also used as a Boarding School Education internalization value to the students. One art that can be used to internalize the value is the Music Arts Education is the art of Qosidah Burdah. The art music of Qosidah Burdah in Boarding School, in addition to encouraging creativity and achievements of students in the fields of art, is also a media internalization of education of values.

Internalization of Values Education through the medium of music art Qosidah Burdah is something quite interesting as study materials in the field of Islamic Culture. Therefore, this paper also explains the problems of answering the question of what value contained Education in the Arts Music Qosidah Burdah, and how the process of internalization committed against students at Boarding School. To answer the question above, will be explained about the Educational Values, Qosidah Burdah and values contained in Qosidah Burdah

\section{Educational Value}

Education is an interesting topic and always real to talk about. One of the topics is about the value of education. Many experts have explained about the educational value of such Kohlberg et.al. (Djahiri, 1992: 27) who explained that Values is engineered towards the promotion and development structures and potential / experience component effectual (affective component and experiences) or "identity" or the human conscience or conscience (al-qolb) humans with the order of values-moral norms, as well as the coaching process of actor (experiencing) and or transaction / interaction affective of someone so that a process of clarification of values-moral norms, submissions value-moral norms or reasoning moral values-norms and or control of moral values-norms. Mulyana (2004) defines the value of education as the planting and development of values and place will be integral in their whole life. Valueof education is not only a special program is taught through a number of subjects, but covers the entire education program. Soelaeman (1987: 14) adds that values of educationis a form of expression of the development activities of existing values through a systematic and critical processes so that they can enhance or improve the quality of learners' cognitive and affective.

Winecoff (1987: 1-3), said that if we talk about education of value, the minimum relate to three dimensions, namely: identification of a core of personal and social values, philosopy and rational inquiry into the core, and decision making related to the core based on inquiry and response. It was also revealed (Hakam, 2005: 5) that the Values Education is education that considers the object from a moral standpoint that includes ethics and norms which include 
aesthetics, namely assessing the object from the point of view of beauty and personal taste, as well as the ethics of assessing true / harm interpersonal relationships. While Dahlan (2007: 5) defines education as a process value of activities which is carried out systematically to give birth to human beings who have committed the cognitive, affective commitment and personal commitment based on religious values. Then, Soelaeman (1987: 14) adds that values is a form of expression of the development activities of existing values through a systematic and critical processes so that they can enhance or improve the quality of learners' cognitive and affective.

From the definition above it can be interpreted that the Education of value is a process of guidance through role models education oriented on planting the values of life which also includes religious values, culture, ethics, and aesthetics towards the establishment of private learners which has a spiritual intelligence religious, selfcontrol, personality intact, noble, and necessary skills themselves, society and the state.

Values education is very relevant to usher in humans in order to survive in humanization level, where behavior is always organized with mental control / mind and conscience. Conscience educational values (values of being), in an effort to provide guidance to the value of human beings and then evolved into the behavior and the way we treat others. Value conscience include: honesty, courage, peace-loving, self-reliability, potential, and discipline, know the limits, purity, and suitability.

Value Education should be a core (essence) of education itself, even Phillips in Boarding School in the Land of Sunda

Combs stated: value education or not all, do not need education if there is no educational value. With the expected birth of Value Education learners qualified human resources, human morality; whose has a sharp conscience, whose life is controlled by the power of conscience in controlling the mental element / thought, emotional and according physical.

In Living Values Education (2004: 1) explained that the goal of Education are:"to help individual think about and reflect on different values and the practical implications of expressing them in relation to themselves, other, the community, and the world at large, to inspire individuals to choose their own personal, social, moral and spiritual values and be aware of practical methods for developing and deepening them". Lorraine (1996: 9) argues: "in the teaching learning of value education should emphasizing on the establishing and guiding student in internalizing and practing good habits and behaviour in their everyday life as a citizen and as a member of society".Objective Value Education according Apnieve-UNESCO (1996: 184) is to assist learners in exploring the values that exist through critical testing so that they can enhance or improve the quality of thinking and feelings. Meanwhile, Hill (1991: 80) believes that value Education is intended for students to appreciate and practice the virtues in accordance with his religious beliefs, consensus society and universal moral values espoused to become his personal character. Simply put, Suparno (2002: 75) observes that the Education are making man virtuous character. Hakam (2000: 8) and Mulyana (2004: 119) adds that values education aims to help learners to 
experience and put the values are integrally in their lives.

In the process of Value Education, measures more specific education is intended to achieve the specific objective. As stated committee of APEID (Asia and the Pacific Programme of Education Innovation for Development), Educational is specifically intended for: (a) applying the value formation to children, (b) generating an attitude that reflects the values that you want, and (c) guiding behaviors consistent with these values. Thus the goal of value Education include educative action which lasts from resuscitation efforts of value until the in the embodiment valued behaviors.

Directions education such as in accordance with the goals of education in general, which is to form the intact human ranging from infants, toddlers, school age children, teenagers, to adults. The formation of personality, personal human ideally should gradually start from infancy to adulthood and continuous lifelong (Sumaatmadja 2002: 121). In other words, the value of education should also be applied in different areas of education such as family, schools, and communities. In the era of globalization as an era of uncertainty, moral human being getting damaged, no civilized human behavior, and community conditions gripping and frightening. The condition arises from concerns about the generation of human life, especially in the formation of the child's personality, and then the value of education becomes a sustainable solution for the formation of a good generation for the foreseeable future.

The purpose of education is the human being, in line with the nature of the goals of education, which is humanizing. Values education aims at helping students to grow and develop into individuals become more humane, useful and influential in society, responsible and proactive and cooperative, personal intelligent, skilled, but still humanist.

Institutions that have been successfully carried out value Education is Boarding School. Value Education in Boarding School has spawned a character education. Value Education of in Boarding School can be done with the internalization process using instructional media. One of the media that can be used for the process of internalization Music of value Education that is Qosidah Burdah

\section{Qosidah Burdah}

Burdah means a robe of leather or fur. At first Burdah has no charge historical value but the designation for a simple sweater or robe worn by Arabs Payload sacred values emerged when one day the Prophet Muhammad presented clothes Burdah, he used to wear to Ka'ab Ibn Zuhair (662 AD) poet renowned newly converted to Islam as a reward for the poem his composition that contains the respect and praise of the Prophet Muhammad and Islam brought (Adib, 2009; 23)

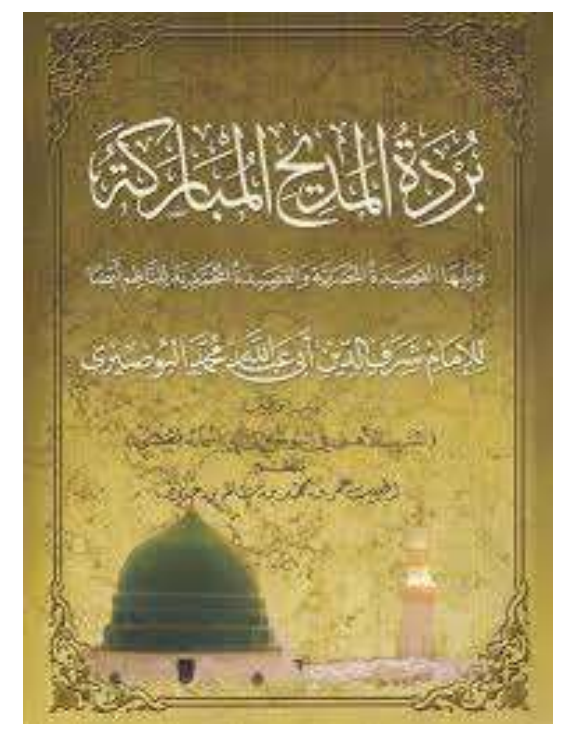


Figure 1 : The Book of Burdah work of Al-Bushiri

Burdah word actually means in the form of a wool coat that can be worn as a robe at a time when day and used as a blanket at night (Baharun, 1996, p 11) E.J. Brill's (1987: 796) in The First Encyclopaedia of Islam 1913-1936 Volume II, wrote two senses Burdah, namely (1) "Apiece of woolen cloth used since pre-Muhammad times, which was worn as a colak bay day used a blanket by night. That of the Prophet has become famous. As a reward for Ka'bb. Zuhayr's poem, he made him a present of the Burda he was wearing. It was bought from the son of o the poet by Mu'awiya and was preserved in the treasury of the 'Abbasid caliphs until the occupation of Baghdad by the Mongols, Hulegu caused it to be burned but it was afterward claimed that the real Burda of the Prophet was saved and ia still preserved in Constantinople. (2) "The name of a celebrated poem by al-Busiri. According to the legend he composed it when he was cured of a paralytic stroke which had seized him by the Prophet's throwing his mantle over his shoulders as he had done on a previous occasion for Ka'ab $b$. Zuhayr. The fame of this miraculous cure spread and the poem, which was entitled al-KawakibalDurriyya fi Madh Khayr al-Bariyya,came to bear the name Burdah..." Burdah is a poem of praise (Madaih) addressed to the Prophet Muhammad written by renowned Abu Abdillah Syarafudin Abi Abdillah Muhammad bin Khammad ad-Dalashi ash Sanhajiasy-SyadziliAlBushiriwhich was then known as Imam Bushiri, as an expression of longing and love in the Prophet Muhammad with all the implications (Poerwadarminta, 2007, p 195) Why is named as blessings and prayers Burdah?

\section{in Boarding School in the Land of Sunda}

Based Bushiri own story, supposedly when he was suffering from paralysis due to a disease called red wind, in his dream he met the Prophet and then the Apostle gives coat (Burdah) it to him, That is the same coat as given Ka'ab, he was surprised and jumped out of bed so that the paralysis did not feel anymore. As soon as he awoke deeply moved and wrote poems known by the title of alkawakib ad durriyah (stars sparkly). The poem contains the praise of the Prophet and because it has to do with a coat given by the Prophet, then later poems are known by the name of al-Burdah. Burdah consists of 160 stanzas, containing advice and warnings for example about the greedy desire, praise to the Prophet, the majesty the Quran, Ascension, jihad warriors of the Prophet Muhammad, prayers and blessings on the Prophet, family, friends.

Qasidah Burdah is actually a reflection of Imam Bushir sufistic experience. His real name is Abu 'Abd Allah Neural ad-Din Muhammad ibn Sa'id bin Hammad bin Muhsin bin' Abd Allah ibn alShanhaj bin Mallal al-Bushiri (Adib, 200911-12) Al-Bushiri attributed to his birthplace, Bushir. The father of al-Bushiri derived from Dallash, so by as-Suyuti, for example, he was also called by al-Dilasi (Brill's, 1987: 804) Al-Bushiri is Syadziliyah followers, as the one of the congregation founded by Sheikh Abu Hasan as-Shadhili. On the basis of the love of God and the feelings of love and longing to His Messenger is great, Imam Bushiri then pour in Burdah. Burdah (Sholawat Burdah) itself is a poem of praise (mada'ih) entitled al Kawakib Durriyah fi Madh al-Khayr alBariyyah (Stars Sheen in Praising Best Creatures), though more popularly known by the name of al-Burdah Qasidah In 
Burdah, contained pearls lesson about respect for the creatures of choice and beloved Lord of the Worlds (Kabbani, 1998: 98)

As other shalawats, Qasidah al Burdah is addressed to Rasullah blessings. These prayers can be used as an intermediary (wasilah) closer to Allah, other than by increasing istighfar course (Huda 2008: 119). Burdah also has a mystical dimension, because emperiences by most Muslims, Burdah often used as wasilah to acquire the intercession and mercy of God. Told that the companions of al-Bushiri own, as-Sahib Baha 'ad-Din ibn Ali ibn Muhammad ibn Salim Hana, an official in Egypt at that time, even ask for a copy Burdah al-Bushiri used to treat blindness one royal servant named $\mathrm{Sa}$ 'd ad-Din al-Fariqi. After Burdah copy it rubbed in her eyes, Syahdan blindness was healed. Since then the as-Sahib vowed to always stand, taking ablution, robes and wearing headgear in while reading a poem Burton dah. All was done as a form of homage to the poem The Prophet's madaih (Adib, 2009: 81-82).

Maulid also referred to as blessings, because when reading it must be accompanied by readingsholawat. Islam itself incorporates this sholawat as one of the preferred Sunnah worship. As stated in the QS al-Ahzab: 56, God promises high rewards for people who do: Verily Allah and His angels to praise the Prophet. O you, who believe, praise to Prophet and say greeting to honor him.

Qosidah is one way of expressing love for a Muslim to the messenger of Allah, the Prophet Muhammad SAW which is done by reciting poems to The Prophet. Imam Al
Bushiri express it through a series of poems entitled Al Kawakibuddruriyah fi Madhi Khoiril Badriyah (Nihayah, 2014; 300)

Qosidah Burdah consists of ten principal themes: (1) Prolog Love of lover numbering 12 verses contain the love of Muhammad. (2) Warning of the dangers of indulgence which are 16 stanzas. Burdah poems in this section contain a warning about the dangers of lust and expressed also the character of lust. (3) Praises of 30 stanzas. Praises Al Bushiri the prophet is not limited to the nature and quality of personal, but it reveals the most important advantages of the prophet, the prophet of the greatest miracle in the form of the Quran, the eternal miracle. (4) The story of the birth of 13 stanzas. Burdah section tells the story of the birth of Prophet Muhammad, along with a variety of amazing events around him as a sign of the birth of the Apostle. (5) Phoenix 16 stanzas. Burdah fifth part is telling about the miracle of miracles of the Prophet Muhammad that are lahiriyah. (6) Al Quran 17 stanzas. In this section tells privilege Phoenix Prophet Muhammad that a descent Scripture Quran as a guide. (7) Ascension 13 stanzas. The seventh part of Burdah is The Prophet said sacred journey from the Haram to Sidratul Muntaha. (8) Jihad 12 stanzas. The struggle illustrates the Prophet Muhammad in the Battlefields. In this section illustrates the story of the struggle of the Prophet, Keperklasaan Prophet Muhammad and his companions in the battle against the enemies of Islam. (9) Repentance and forgiveness petition by 12 stanzas. In this Burdah Imam Al Bushiri describe penyhelasan deep on Al Bushiri habits that make poetry with mengharapan material. (10) The cover consists of 10 stanzas. In this section looks proficiency Al Bushiri in expressing Matla. At the end of this chapter, 
$\mathrm{Al}$ Bushiri constructs a sentence as beautiful as possible. In this section, too, is the hope that $\mathrm{Al}$ Bushiri unforgivable sins of his (Syed Mohiudin Qodri, 2008; 33)

In couplets of Qosidah contain about devotion to Rasullah. It is described in the temple of 1-12. This verse contains prologue in the study of science called algharam syakwa (inner expression of the poet) (Adib, 2009: 33). In this section, the poet reveals his heart with figurative and symbolic language (hyper- boluses). In the early stanzas he showed a sense of his love to the Prophet, with a story that begins with fate, the expression of melancholy over the grief experienced by poets and people close to him, that his neighbors in Dzu Salam. Unusual for classical Arab poets when began his poem which is always refers to the place where he gained deep memories in his life, especially about my hometown (Qadri, 2008: 9)

In addition to the love of Muhammad, Qosidah Burdah also contains advice would lust. Related to this lust, alBushiri reveal the character of lust. In parse control lust, al- Bushiri recommends that the will of lust thrown away, not to be pampered and maintained, because it is misguided and misleading. The state of hunger and satiety, they both can damage both, then it should be in order to be kept in balance. Solicitation and inducement lust of the devil should be resisted tooth and nail. It also contains praise to the Prophet who started from the temple of all 29 to 58. Praise al Bushiri to the Prophet is not limited to the nature and quality of personal, but it reveals the advantages of the Prophet foremost, that the miracle tangible existence of al-Qur ' an. Qur'an is a book which contains no doubt and not decayed by in Boarding School in the Land of Sunda

the changing times. Especially when interpreted and understood in a wise and knowledge-based ma'rifat. Lessons and content of the Qur 'an always have relevance to the historical events that are temporal. alQur 'an lives forever in the memory and spirit of Muslims. This part is the core part of Burdah, that is of the Prophet.

At line 59 to 71 Qosidah Burdah contains Maulid Nabi SAW. This section tells the story of the birth of Prophet Muhammad, as well as a variety of amazing events that mark his birth. Lines 72 to 87 contain about miracles. This section tells about the miracles of the Prophet, which is outward. Part ensuing said various privileges miracles of the Prophet, through reduction in the Qur'an as a guide. In part seventh section events sacred journey of the Prophet, from the Haram to Sidratul Muntaha (Isra 'Mi'raj). The eighth section contains stories of struggle and courage of the Prophet and their companions in the battlefield. Part ninth contains remorse and plea for forgiveness. In this line, al-Bushiri described deep remorse over his habit of writing poetry with the expected material. Burdah covered with fragments of the cover and prayer. In it, it appears that al-Bushiri is good at expressing matla 'with a sentence that is so beautiful that parse hopes al-Bushiri so unforgivable sins. (Qadri, 2008).

For the Boarding School, Qosidah Burdah had a religious function. Burdah where it can be seen through the practice of abortion. The practice of towing argument that Burdah was aligned with al-Qur'an and Sunnah, following the Prophet's love and respect for the scholars'. They view alBushiri as a viable Waliyullah expected blessing. In addition Qosidah Burdah has a magical function, such as treating the 
physical and spiritual disease as well as a repellent reinforcements'. In this regard, Burdah also looked adorn religious ceremonies, agriculture, commerce, commanding the good and forbidding unjust. Another function of Qosidah Burdah is for educational function, where Qosidah Burdah for students and the community are as one source of Islamic teachings related to how to love, praise and emulate the Prophet, and the latter is a function of entertainment and conditioning heart that used to motivate students. These functions will work if done by internalization Value Educationof the values contained in Qosidah Burdah.

\section{Value Education In Qasidah \\ Burdah}

Value Education in Boarding School is part of the essence of public education. Value Educationin Boarding School can be devided in various forms, such as the value of doctrine / teachings, cultural values, with the literary and musical values. Boarding School is an educational institution that prioritizes value education. Priority value education is important, since the foundation in the construction of the personality of students, so that by itself it is able to independently orient themselves into a complete human being (insan kamil) at a later date.

Boarding School try to optimize the value of education within students. The values instilled such is the value of theology (usul al-din), juridical value (fiqh), sociocultural values of Islam, Sufi and other values. At the application level, all these values instilled proportionally and continuously. Proportionally it is intended that the existing values are internalized in accordance with the competence of cognitive, affective, and psychomotoric of students, so the potential thinking, hearts, and charities students can develop psychological and physiological harmony. Value theological (usul al-din) implanted with the aim of constructing a paradigm of faith of students, so that he can be consistent with the teachings of the Quran and Sunnah in pure faith in Allah Almighty, with no infected behavior of heresy, superstition, and myth.Juridical value (fiqh) implanted with the aim to form students of the schools and the private law-abiding both in worship and mua'malah, and be able to control ourselves not to do those things which are prohibited religion. Socio-cultural value of Islam implante with the aim to establish private students who are able to develop themselves as social beings, who by his existence it can be beneficial to the environment and society, and is able to propose solutions to the problems of socio-cultural values in society. Sufistic value implanted with the aim to establish private students who could organize his heart clean of all impurities heart and soul disease, both emerging from lust, temptation Satan and bad values from public life and the negative impact of modernization and globalization. Sufistic value investment process in Boarding School one of them through the weekly recitation and study of the Book of Classical Islam and its practice (Ainusyamsi, 2008: 23 ). The values sufistik previously implanted through the application of traditional teaching, which is only by reading the (accent), later described his understanding. But to give a deepening passion and meaning especially for enlightening people to the students, at Boarding School held internalization of Sufi values through music. One of the example is the musical Qosidah Burdah. 
Internalization of values education through music Qosidah Burdah is done in an effort to planting mental education in order to provide an understanding of religious attitudes and the development and growth of a person. In addition to the prevention of bad qualities, teaching materials can also be expected to heal. Technique of heal the soul for students who are troubled, restless and depressed by describing the values sufistic that is integrated into the musical Qosidah Burdah. In Burdah qosidah music lyrics that are taught in the Pondok Boarding School are the sufisticvalue which can be classified into two, namely Sufistic value and the value of ideals.

ValueEducation contained in Qosidah Burdah include:

Line -1 is aboutsyauq (yearning )

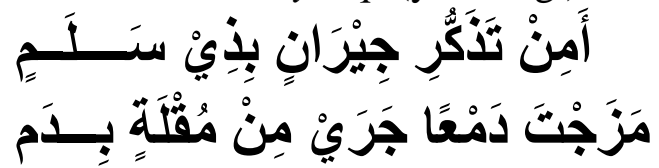

A min tadzakkuri jiranin bi Dzi Salam

Mazajta dam 'an jara bi muqlatin bi dami

(Do you remember why the neighbors who are in Dzi Salam)

(Until you are mixing tears with blood dripping from your eyes)

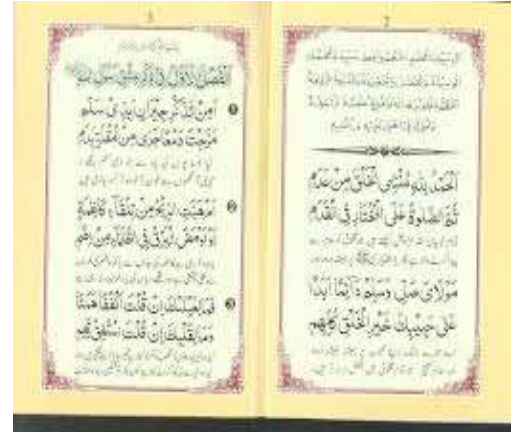

Figure 1. Teks of Burdah Al Bushiri

Syauq in line -1 described bytadzakkuri (everlasting bethink), dam'an (tears) anddami (blood). Kata-kata tersebut mengindikasikan klimaks kerinduan, diilustrasikan dengan seorang yang terus

\section{in Boarding School in the Land of Sunda}

menerus ingat kepada seseorang, yang ingatannya tak dapat hilang dari memorinya.. The word is derived from the word dzakara tazakkur which means remembering, and then formulated with wajan isim masdar "tafa'ala" that has meaning to remember "continuous" yearning water mark is symbolized by tears mixed with blood. The weeping shape means that the yearning is not accompanied by the usual cries. The cries tears of blood is crying protracted, where the heart desires unfulfilled. A wonderful fantasy of someone who reflects the memory of the lover who was at his side.

Line -12this aboutmachabbah (love)

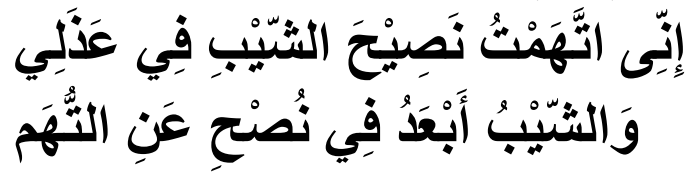

Innit-tahamtu nashichasy-syabi fi 'adzali

Wasy-syaibu ab'adu fi nushchin 'anit tuhami

(Indeed, I suspect that advice, even if that advice from my gray)

(while the gray hair to advise should not be suspected)

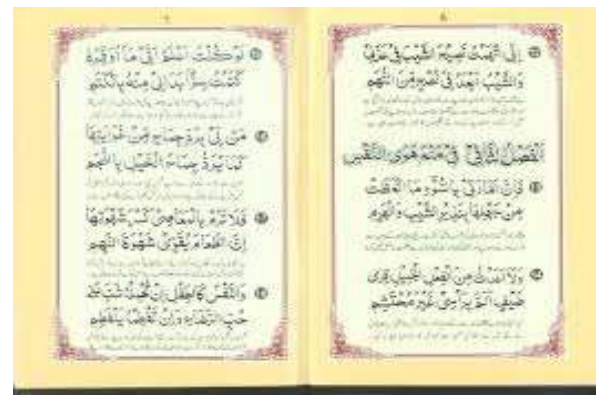

Figure . 2 Teks of Burdah Al Bushiri

Machabbah on the line 12th in the show in the sentence innit-tahamtu nashichasy-syabi fi 'adzali (Indeed, I suspect that advice, even if that advice from my gray). Gray hair is a hallmark in the human head which shows that a person's age is old. Gray hair shows that as far as any human 
effort to achieve something of the limitations that prevented, since man is not God who has no limitations. God gives gray hairs in the human head as a warning of the limitations of age, and human beings can not be young and immortal. But for people stricken love is not going to bother with that mark. Because love can be brought to death, love makes a person it is as if life although he had been dead. Love is the sign of the power of God for man who can pass the age limit.Many monuments, buildings, or symbol in the world that became a symbol of true love that will live, even though the owner of love has gone. One of the examples is Taj Mahal.

In the early literature science writing or muqadimah of ordinary poem called syakwa al-gharam (inner expression of the poet) (Adib, 2009: 33). In this section, the poet reveals his heart with figurative and symbolic language (hyperbolic). The beauty in the preparation matla '(the beginning of the stanza Burdah) demonstrate the skill of a poet. Here, the poet will deploy all its capabilities (Baharun, 1996: 19). Imam alBushiri arrange matla 'Qasida Burdah imagine as if he was in a confused state and unconscious, he wondered to himself who had a deep longing, to shed tears of blood. On the other side of him, often reprimanded her longing. miss (syawq) is characteristic of people who are in love. This situation shows mahabbah of al-Bushiri to the Prophet Muhammad.

Al-mahabbah, or love, According to al-Ghazali, was the highlight of our religious journey. Literally the word comes from the word mahabbah habba, yuhibbu, mahabbatan, means love deeply, or a deep love. Mahabbah can also come from hubbun word which means love, and it could be from habba-hubban word which means love or like, and can also implies al-hawa which means love, love. Most Sufis say that hubb consists of two words, ha and ba. Letter ha means soul, and $b a$ means body. Therefore, $h u b b$ the spirit and body of our religious process (Jalaluddin Rachmat, 2000: 16-17). Mahabbah is love. Love is something that soar above the water when heavy rainfall. On top of this love heart is boiling and overflowing when thirsty flared increasingly longing to meet her lover. It also said that love etternally, as if the people who fall in love that his heart would never forget to remember his lover. It also said that love because love bear poles of pleasure and pain (al Qushayri, 2007: 477-478).

It was difficult to know the notion of love is definitive, kecual when we love and be loved directly. Meanwhile al-Bushiri in his in Burdah, giving expression and figurative love he experienced the love and longing for the 'lover'. The entire spillage of love and longing are for the Prophet, above all the nature and the turmoil of her love. AlBushiri also said that people who have fallen in the garden of love, he could no longer ignore all the advice of others, but to the ourselves the idol's heart. Love and longing expressed to the line 1-12.

Line-13 is abouttarku al-syahwat (abstinence)

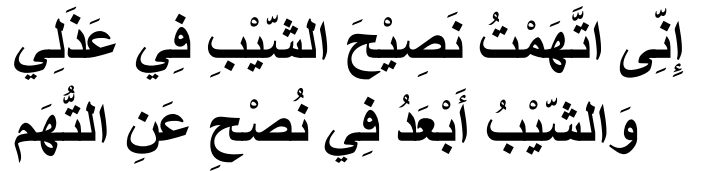

Fa inna ammarati bis-su'i mat-ta'azhat

Min jahliha bi nadzirisy-syaybi wal-harami (Indeed lust anger)

(Not willing to accept advice from my gray and my nature, because it was stupid lust) 


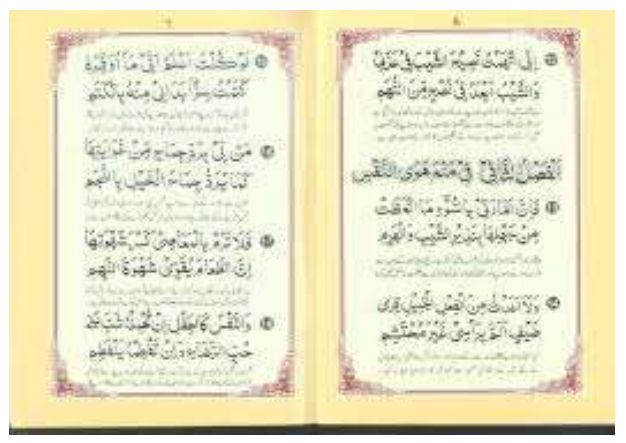

Figure . 3 Teks of Burdah Al Bushiri

In line 13th Qosidah Burdah, passion pictured with sentence of $\mathrm{Fa}$ inna ammarati bis-su'i mat-ta'azhat, Min jahliha bi-syaybi nadzirisy wal-Harami (actually lust anger was not willing to accept advice from my gray and nature my, because passions are stupid). If lust master of one's soul, then all goodness will not be accepted, because the passion is synonymous with ignorance. Stupidity does not mean smart or not knowledgeable, but it is an attitude of "do not want to know" the truth, because the passion for healthy deadly logic. Gray hair is a sign of the age of man, that is a warning for people not to spend ages with lust. Because the passions always end up with evil, then Allah SWT give gray hair a sign that people realize that life does not end with $s u$-ul khatimah.

The line $-26^{\text {th }}$ is aboutmuchasabah al Nafs (self-intropection) andTaubah (repentance)

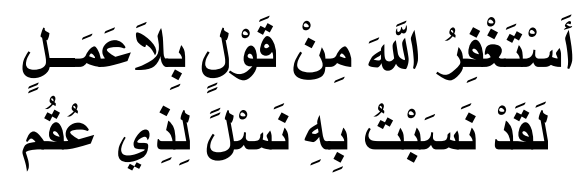

Astaghfirullaha min qaulin bi la amalin La qad nasabtu bihi naslan li dzi uqumi (I ask for forgiveness to God from the words without deeds)

(Really saying that I assume the child out of the barren).
In line the 26th, muchasabah alnafs is expressed in the sentence Astaghfirullaha min qaulin bi li la amalin and naslan Dzi uqumi. That man should be me-muchasabah himself, who consciously or unconsciously have sinned, unjust, and negligent, and that every human being has the disadvantages of each. Attitude muchasabah al-nafs turn our attention to oppress others with our bad deeds. Istighfar (begging forgiveness) to Allah SWT is an advanced process of muchasabah al-nafs to be cleansed of all sins, unjust and negligent including rid yourself of attitudes mismatch word and deed

The second part of the poem Burdah contain a warning about the dangers of lust. This term is generally used in Sufi psychology. According to Al-Tirmidhi cited by Amir An Najar (Muradi, tt: 15-16) soul has three meanings: (1) nafs (soul) that can provide meaningful breath of life, which was scattered breath of the soul, like the overflow of something from above down. (2) nafs (soul) as gharizah (instinct) is decorated by satan with all forms of trickery, which aims to win and ruin. In this position, the soul is very weak in front of Satan. (3) nafs (soul) as a friend and helper demons, and soul this night participating in a crime, even a part of the crime itself. While the character of lust could plunge man in the valley of humiliation. Associated with lust, al-Bushiri in his reveal the character of lust in Burdah, the numbers there are 16 line started from line 13-28, line -30 th is about personal ascetic(hereafter orientation)

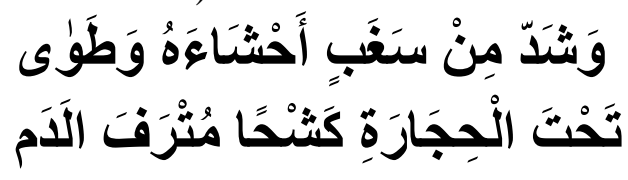


Wa syadda min saghabin achsya-ahu wat thawa

Tachtal hijarati kasychan muthrafal adami

(That man (the Prophet) bind her stomach because hungry)

(Until he tied stones in its stomach that fine skin, it just starve)

One of the ascetic behavior performed by the Prophet Muhammad contained in qosidah Burdah line all 30 listed in sentence Tahtal hijarati kasyhan muthrafal adami (he tied a stone to his stomach which was just fine skin, resist hunger). Hunger is one of the ascetic methods. Hungry opponent from satiety. If humans are a glut of brain and heart will sleep, while lust will rise. Fitness lust was in the belly. Hunger means that efforts to control lust, but expand opportunities for the brain to think and the heart to feel. Prophet Muhammad willing to starve to wrapping the stones in its stomach to withstand the pangs of hunger, so hungry it does not interfere with worship to God.

Line $-35^{\text {th }}$ is aboutabout personal godly

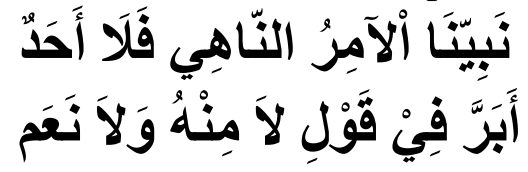

Nabiyyunal amirun nahi fa la ahadun Abarra fi qawli la minhu wa la na 'ami (Our prophet who always ordered kindness and always forbidding the evil)

(Nobody is better in word and deed than he)

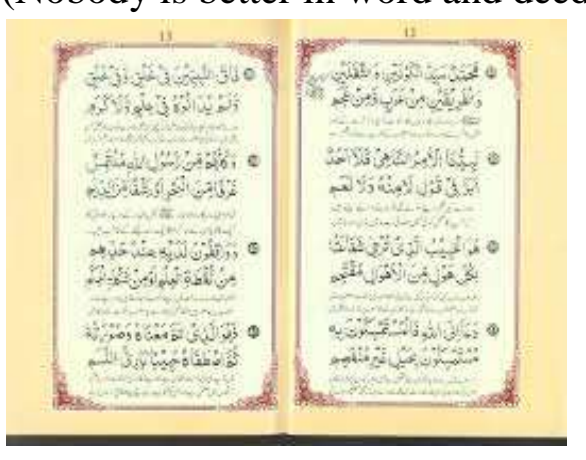

Figure . 4 Teks of Burdah Al Bushiri

In this line, godly is contained in the sentence Nabiyyunal amirun nahi fa la ahadun, Abarra fi qawli la minhu wa la na 'ami of our Prophet (Muhammad SAW) who always ordered (kindness) and always prevent (from evils). So no one is better in word and deed compared with him. Is the command of the Prophet Muhammad told his followers to always be godly. Most of his time there is excessive or outside the standard in doing obedience to Allah Almighty, so that his actions were in violation of the limits of human nature. So in this case, the Prophet Muhammad is an example of personal piety.

The third part contains the praise of the Prophet Muhammad privileges. This section is the core of Burdah is about the Prophet Muhammad. When praise him SAW. including worship and prayers, then Burdah also said prayers/ sholawat. This chapter starts from line of 29-58. The values contained therein are compliments of all zuhudan Prophet Muhammad came to Itself and Nur Muhammad. About zuhd etymologically rooted in the word al Zuhd, masdar of words zahada or Zahida, zahada fi al-syai'i au'anhumeans raghiba 'anhu means leaved and disliked. Zahada fi aldunya means to abstain from the pleasures of the world to worship. People who do ascetic called al-Zahid means people leaving worldly pleasures and choose the Hereafter (Munawwir, 1997: 588). Later in the Encyclopedia of Islam Indonesia, noted that zuhd against something means not enamored by it. In a study of Sufism, said zuhud usually associated with the world (worldly pleasures covering material or physical pleasure, wealth, rank, etc.). Zuhd the world 
means not to love the world, not interested, do not be tempted, and not be carried away by worldly pleasures (Nasution, 1992: 1011).

Sheikh Abdul Qadir Jilani in Adab as-Suluk wa at-Tawassul ila al-Muluk Manazil (al-Jilani, 2010: 205), said two things asceticism, namely worldly asceticism and ascetic hereafter. First, anyone who desires the Hereafter, he must ignore the world. If the desire for the world (such as eating, drinking, dressing, getting married, property, vehicles, office, etc.) still exists in the mind of a person, then he is not among the pious. Because, in all worldly desires no pleasure for human beings and harmony with the will of the flesh, the pleasure of life and love. These things are earthly life, in which people love kindness, and with people trying to get the satisfaction and peace of soul.

Second, whoever Allah wills, then it is obligatory for her ignore the hereafter. Hereafter is like a desire, and the position requires a high degree, servants gorgeous, houses of heaven, and so forth, what God has prepared for ministers who have faith in Him. So do not try to get revenge for something action of God in this world and hereafter.

He also said that people who ascetic reward twice. First, because of his rejection of the world, so that she does not love him and follow his lust, but he was just following orders. If he has really become the enemy against their natural tendency of passions and desires, then he belongs among the masters of sainthood, and inserted into the inner ranks of Abdal and the 'Arif bi Allah. if it is so, soon after which he was ordered to get in touch and engaged with the world, because the world is a part that should be taken, and not created for much more, the pen had dried writing and science unanimously decide (al-Jilani, 2010: 194).

line- $77^{\text {th }}$ is abouttawakkal (surrender)

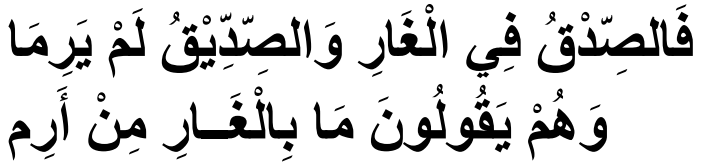

Fash-shidqu fil ghari wash-shidqu lam yari Wa hum yaquluna ma bil ghari min arami (The righteous (Prophet Muhammad) and that justify (Abu Bakr AS) in a cave dd not go)

(But those who disbelieve say that in the cave there is no one living)

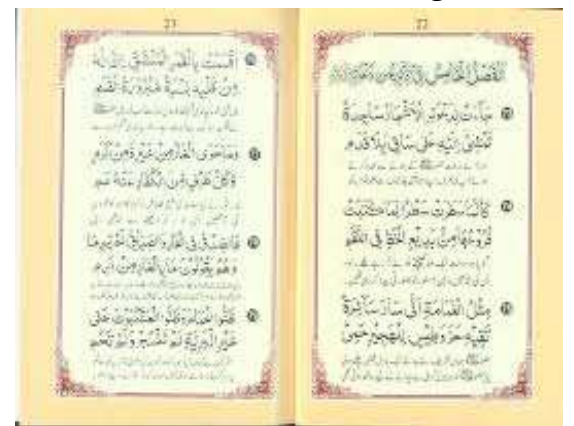

Figure. 5 Teks of Burdah Al Bushiri

In line 77th illustrates the chronology glance hijrah of the Prophet Muhammad who accompanied Abu Bakr (peace be upon him) to Yathrib. At the time of hijrah, the status of the Prophet Muhammad is "fugitive" Quraish that must be captured dead or alive. This status is applied by pagans as presedence of their conspiracy to remove the teachings of Islam and its leader. All the tribes in Mecca involved in this conspiracy, making it possible to survive a very thin one. Prophet Muhammad remains effort to get out of his house, then seeked unusual pursued by the Quraish tribe to Medina, so the Prophet Muhammad decided to stay for a while in the Cave of Thawr. In the cave of the Prophet Muhammad and his companions Abu Bakr US surrendered to Allah SWT will be the 
fate of their lives both by saying: .... "Innallaha ma'ana" (verily Allah is with us). Then Allah also break the logic of the disbelievers by presenting spider ('Ankabut) and pigeons (hamam) in the mouth of the cave so that they believe that the prophet and his companions did not exist in the cave of hiro.

See verse from qosidah Burdah above, looks full of moral and educational values. The values syauq (longing), mahabbah (love), tarku al-lust (abstinence), muchasabah al-nafs (self reformation), Taubat (repentance), zuhud (orientation hereafter), personal asceticism, personal piety, personal trust can be internalized in everyday life of the students in the Boarding School. Among examples of the behavior of students, namely (1) honesty in all actions, (2) said fine and true to anyone and if it can not be said well then better still, (3) carry out the mandate of the parents, the mandate of the teacher, the mandate of the people other, (4) trying hard to fight, uphold truth and strive to achieve success with full awareness and semanagt seek the blessing of Allah, (5) love to seek knowledge in order to quality, (6) likes to read sholawat on prophet Muhammad, ( 7) does not break a promise, (8) to implement or comply treatise that has been conveyed by the Prophet.

\section{Closing}

As other educational institutions, the purpose of the education system Boarding School is to produce learners who are faithful and devoted. This can be achieved by inculcating education, through Value Education to the students or learners. One of the efforts undertaken by the Boarding School is by internalizing the value Education of students. Internalization of Value Education can be done through the medium of art that is Qosidah.

Qosidah for Boarding School students and the community, not just a mere entertainment media, but more than that may be forming a positive attitude. This is because the music Qosidah able to bring entertainment besides music also can give birth to music therapy. Besides it is useful in expressing feelings, music Qosidah could also become creators to realize themselves (society of boarding house) as a whole (selfactualization) as one of the basic necessities of human life. Qosidah itself has a creative dimension (al-janib al-ibtikary) and has a section which is identical to the learning process in general in music contained an analogy Qosidah through perception, visual, auditory, anticipation, inductive-deductive reasoning, memory, concentration and logic.In Qosidah music can be characterized and studied in various speed fast-slow, lowhigh, hard-soft, which is useful to train students sensitivity to environmental stimuli both in and outside the Boarding School or Boarding School. For students or people Boarding School, Qosidah musical art can be used as a tool to improve and help the personal and social development include aspects of cognitive ability, reasoning, intelligence, creativity, reading, language, social, behavioral, and social interaction 


\section{REFERENCES}

Adib,M.(2009). Burdah; Antara Kasidah, Mistis dan Sejarah.Yogyakarta: Pustaka Boarding School.

Al-Jailani, Abdul Qadir, Rahasia Sufi, terjemah:

Abdul

Majid,(Yogyakarta: Pustaka Sufi,2002)

Al-Qardhawy. (2001), Fiqh al-Ghina wa alMusiqy fi Dhau-I al-Quran wa al-Sunah, Cairo, Maktabah Wahbah.

Al-Qusyairi, Al-Risalah Al-Qusyairiyah Fi 'Ilmi al-Tashawwuf, (Bairut:Dar al-Kitab al-Arabi, tt)

Hasan, Basri,2001, Boarding School : karakteristik dan unsur-unsur kelembagaan, dalam dalam Abuddin Nata "Sejarah Pertumbuhan dan Perkembangan Lembagalembaga Pendidikan Islam di Indonesia" Jakarta, Grasindo

Djohan. (2005), Psikologi Musik, Yogyakarta, Buku Baik.

Djohan. (2006), Terapi Musik: Teori dan Aplikasi, Yogyakarta, Galang Pers.

Djahiri, 1992, Panduan Metodologi Pengajaran Pendidikan Nilai Moral, Bandung, Lab. PMP, IKIP Bandung

E.J. Brill's, The First Encyclopedia of Islam, (Leiden, t.p, 1987) jilid I hal.796

Fadlil Yani Ainusyamsi. (2008), Studi Tentang Internalisasi NilaiNilai Sufistik Melalui in Boarding School in the Land of Sunda

Musikalisasi Qosidah Burdah, Bandung, UPI.

Gazalba. (1998), Islam dan Kesenian: Relevansi Islam dan Seni Budaya, Jakarta, Penerbit Pustaka Al-Husna.

Hakam, Kama Abdul, 2005, Nilai Sosial Budaya dalam Pendidikan Umum, Bandung, Universitas Pendidikan Indonesia

Hakam, Kama Abdul, 2002, Pendidikan Nilai, Bandung, Values Press.

Huda, Sokhi, Tasawuf Cultural, PT LKiS Pelangi Aksara, 2008

Jacques, Delars, et all, 1996, Learning : The Treassure Within, Laporan untuk Komisi Internasional UNESCO mengenai Pendidikan di Abad 21, Jakarta, UNESCO Publishing.

Kabbani,S.H.(1998).EnergiZikirdanSalawa t. (terj.Z.Am)Jakarta:Serambi.

Kohlberg, L. 1971. Stages of moral development as a basis of moral education. Dlm. Beck, C.M., Crittenden, B.S. \& Sullivan, E.V.(pnyt.).Moral education: interdisciplinary approaches, New York: NewmanPress.

Kohlberg, L. 1977. The cognitivedevelopmental approach to moral education. Dlm. Rogrs, D. Issues in adolescent psychology, New Jersey: Printice Hall, Inc.

Mulyana, 2004, Mengartikulasikan Pendidikan Nilai, Bandung, Alfabeta. 
Jurnal al-Tsaqafa Volume 15, No. 02, Desember 2018

Poerwadarminta, 2007, Kamus Umum Bahasa Indonesia, Jakarta. Balai Pustaka

Qadri,S.M.(2008).Qasidatal-Burdah;The Poem of the Mantle. Dikutip Juni 6, 2015, dari http://creativecommons.org/li cences/by-nc-sa/in.

Khan. (1996), The Mysticism of Sound and Music, London, Boston Pers.

Mastuhu, 1994, Dinamika Sistem Pendidikan Boarding School, Jakarta, INIS,

Muhaya. (2003), Bersufi Melalui Musik: Sebuah Pembelaan Musik Sufi oleh Ahmad al-Gazali, Yogyakarta, Gama Media.

Nakagawa. (2000), Musik dan Kosmos: Sebuah Pengantar Etnomusikologi, Jakarta, Yayasan Obor Indonesia.

Nihayah, Ulin, (2015), Qasidah Burdah Imam Al-Bushiri; Model Alternatif Dakwah Boarding School, Jurnal An-Nida Jurnal Komunikasi Islam Volume 7 (1), Fakultas Dakwah Universitas Islam Nahdlatul Ulama Jepara

Setiawan, Eko, ( 2015 ), Nilai-nilai Religius Dalam Syair Shalawat Burdah, Jurnal Lingua, Volume 10 Nomor 1,

Sumantaatmadja, 2002, Pendidikan Pemanusiaan Manusia Manusiawi, Bandung, Alfabeta.

Suparno, P, dkk. 2002, Pendidikan Budi Pekerti di Sekolah Suatu Tijauan Umum, Yogyakarta, Kanisius.
Tilman, Diane, 2004, Living Values : an Educational Program, Living Values Activities dar Children Ages 8-14, Pendidikan Untuk Anak Usia 8-14, Jakarta, Grasindo

Winecof, Herbert Larry, 1987, Value Educational Content and Model,1 Bandung, PPs IKIP 